\title{
Apoptosis Promoter
}

National Cancer Institute

\section{Source}

National Cancer Institute. Apoptosis Promoter. NCI Thesaurus. Code C18567.

A protein that promotes the initiation, progress, or rate of apoptosis. 